\section{PELATIHAN \\ PEMOGRAMAN LARAVEL PADA SISWA SMA IT PLUS BAZMA BRILLIANT}

Nur Budi Nugraha', Tri Handayani², Tri Yuliati ${ }^{3}$, Ari Sellyana ${ }^{4}$

${ }^{1,2,3,4}$ Sekolah Tinggi Teknologi Dumai

*Nur Budi Nugraha

Email : nurbudinugraha@sttdumai.ac.id

\section{Abstract}

The corona virus outbreak affects various aspects of life, including the field of education. SMA IT Plus Bazma Brilliant during the online learning period has used e-learning in its teaching and learning activities. Teachers in utilizing information technology, must be creative. The number of students who want to learn programming laravel framework to make applications so that they learn through social media ranging from youtube, facebook or links on google. However, even though they are learning on their own, students still find it difficult because there is no teacher to guide them. There are some students who don't really understand programming, one of which is Laravel programming because of the lack of direct assistance during this COVID-19 pandemic. The purpose of this service is to provide training to students in understanding Laravel framework programming. The method used is through lectures and discussions followed by direct practice using the Laravel framework which is guided by the service team. The results of this service. Participants who took part in the training felt happy and satisfied with this service activity, this could be seen from the expressions of satisfaction and enthusiasm of the participants listening and asking various things about the material that had been given by the devotees. This service activity is considered by the participants as a means of introducing and learning the Laravel framework as a basis for learning programming to create a simple project Keywords: framework; laravel; daring; student

\begin{abstract}
Abstrak
Wabah virus corona mempengaruhi berbagai aspek kehidupan, tak terkecuali bidang pendidikan. SMA IT Plus Bazma Brilliant selama masa pembelajaran daring sudah menggunakan e-learning dalam kegiatan belajar mengajarnya. Guru dalam memanfaatkan teknologi informasi, harus kreatif. Banyaknya siswa yang ingin belajar pemrograman framework laravel untuk membuat aplikasi sehingga mereka belajar melalui media sosial mulai dari youtube, facebook ataupun link yang ada di google. Akan tetapi walaupun belajar sendiri, siswa masih merasa kesulitan karena tidak ada guru dalam membimbing mereka. Ada beberapa siswa yang kurang begitu paham tentang pemrograman salah satunya pemrograman laravel karena kurangnya pendampingan secara langsung selama masa pendemi covid 19 ini. Tujuan pengabdian ini adalah untuk memberikan pelatihan kepada siswa dalam memahami pemrograman framework laravel. Metode yang digunakan adalah melalui ceramah dan diskusi dilanjutkan dengan praktek langsung menggunakan framework laravel ayng dibimbing oleh team pengabdian. Hasil dari pengabdian ini Peserta yang mengikuti pelatihan merasa senang dan puas dengan kegiatan pengabdian ini, hal ini terlihat dari ungkapan kepuasan serta keantusiasan peserta mendengarkan dan bertanya berbagai hal tentang materi yang telah diberikan oleh para pengabdi. Kegiatan pengabdian ini dianggap oleh peserta sebagai sarana pengenalan dan pembelajaran framework laravel sebagai dasar belajar pemrograman untuk membuat sebuah projek sederhana

Kata Kunci: framework; laravel; daring; siswa
\end{abstract}


Pelatihan Pemograman Laravel pada Siswa SMA IT Plus Bazma Brilliant

Nur Budi Nugraha, Tri Handayani, Tri Yuliati, Ari Sellyana

Vol. 1, No. 2, Agustus 2021 hal. 130-136

DOI Artikel : 10.46306/jub.v1i2.28

\section{PENDAHULUAN}

Wabah virus corona mempengaruhi berbagai aspek kehidupan, tak terkecuali bidang pendidikan. Aktivitas pembelajaran semua jenjang pendidikan di Indonesia dilakukan dari rumah (Fransisca, Saputri, \& Yunus, 202I). Mempertimbangkan efektivitas, keamanan dan kenyamanan, metode pembelajaran online secara penuh menjadi pilihan di tengah pandemi yang diharus pembatasan sosial. Kementerian Pendidikan dan Kebudayaan pun memperpanjang masa belajar dari rumah karena situasi yang belum kondusif (IImi, 2019). Dengan mempertimbangkan efektivitas, keamanan, dan kenyamanan, pembelajaran dalam jaringan (daring) dipilih hampir di seluruh jenjang pendidikan di Indonesia termasuk instansi Sekolah Menengah Atas (SMA) (Tujni \& Megawaty, 2018).

SMA IT Plus Bazma Brilliant selama masa pembelajaran daring sudah menggunakan e-learning dalam kegiatan belajar mengajarnya. Sistem pembelajaran daring merupakan sistem pembelajaran tanpa tatap muka secara langsung antara guru dan siswa tetapi dilakukan melalui online yang menggunakan jaringan internet (Oktaviani, Rini, Ulfah, \& Andriana, 202I). Guru harus memastikan kegiatan belajar mengajar tetap berjalan, meskipun siswanya berada dirumah. Guru dalam memanfaatkan teknologi informasi, harus kreatif (Nugraha, Julanos, \& Suarlin, 2020). Materi pembelajaran diupayakan yang semua peserta didik dapat menerima dan juga tidak kesulitan dalam mengaksesnya (Ikhwani, Hasbi, \& Andie, 2018).

Bahasa pemrograman merupakan dasar dari semua pembelajaran dalam membuat aplikasi salah satunya pemrograman framework laravel (Mahfudin Nawawi, 202I). Laravel merupakan open source framework (kerangka kerja dengan sumber terbuka) berbasis bahasa pemograman PHP yang menggunakan konsep model view controller (MVC) (Laurina, 2020). Banyaknya siswa yang ingin belajar laravel untuk membuat aplikasi sehingga mereka belajar melalui media sosial mulai dari youtube, facebook ataupun link yang ada di google. Akan tetapi walaupun belajar sendiri, siswa masih merasa kesulitan karena tidak ada memtor dalam membimbing mereka. Ada beberapa siswa yang kurang begitu paham tentang pemrograman salah satunya pemrograman laravel karena kurangnya pendampingan secara langsung selama masa pendemi covid 19 ini (Hapsari, Komputer, \& Unggul, 2020). Ketika siswa mengalami kebuntuan dalam mengcoding, siswa menjadi bingung.

\section{METODE PENGABDIAN}

Pengabdian masyarakat dilakukan dengan pendekatan sosial. Pendekatan sosial dilakukan dengan melibatkan kelompok sasaran sebagai subyek kegiatan, tidak hanya sekedar objek kegiatan. Pendekatan sosial dilakukan dengan melibatkan kelompok sasaran dalam proses persiapan untuk menumbuhkan kesadaran bahwa mereka mempunyai masalah seperti yang dirumuskan dan perlu dilakukan pemecahan masalah. Pendekatan sosial ini juga diperlukan untuk memberi jaminan kelancaran pelaksanaan kegiatan. Secara garis besar kegiatan pelaksanaan dilakukan dalam 3 tahap yaitu persiapan, pelaksanaan, evaluasi dan pelaporan.

\section{A. Persiapan.}

Adapun kegiatan dalam proses persiapan adalah sebagai berikut :

I. Analisis situasi dan kebutuhan masyarakat.

Tahap ini dilakukan untuk menentukan kalayak sasaran dan bidang permasalahan yang akan diselesaikan. Pada tahap ini dilakukan survei ke SMA IT Plus Bazma Briliant. Disamping survei juga dilakukan wawancara langsung kepada kepala sekolah dan Siswa SMA IT Plus Bazma Briliant tentang kendala dan kelemahan siswa dalam belajar pemrograman otodidak dalam membuat sebuah aplikasi sederhana.

2. Identifikasi Masalah

Berdasarkan hasil analisis situasi dan kebutuhan dilakukan identifikasi dan perumusan masalahmasalah khusus yang dihadapi oleh kelompok sasaran. Dalam hal ini kelompok sasaran adalah siswa 
Pelatihan Pemograman Laravel pada Siswa SMA IT Plus Bazma Brilliant

Nur Budi Nugraha, Tri Handayani, Tri Yuliati, Ari Sellyana

Vol. 1, No. 2, Agustus 2021 hal. 130-136

DOI Artikel : 10.46306/jub.v1i2.28

SMA IT Plus Bazma Briliant yang mengalami kesulitan dalam pemahaman belajar memahami bahasa pemrograman selama belajar daring. Sebagian besar siswa kurang memahami dalam membuat sebuah program dan menganalisa jika terjadi error dalam coding

3. Menentuan Tujuan

Pada tahap ini ditentukan kondisi baru yang akan dicapai/dihasilkan melalui kegiatan pengabdian masyarakat ini. Kondisi baru adalah jawaban dari masalah yang telah dirumuskan. Tujuan dari pengabdian ini adalah siswa mampu memahami permograman laravel serta mampu menganalisa jika terjadi error dalam coding.

4. Rencana Pemecahan Masalah

Masalah yang sudah diidentifikasi perlu dipecahkan dan sekaligus mencapai tujuan (kondisi baru) yang telah ditetapkan. Pada tahap ini dilakukan dengan mencari alternative pemecahan masalah dan selanjutnya memilih alternatif terbaik yang dapat dilakukan dengan memperhatikan situasi dan kondisi kelompok sasaran dan pelaksana kegiatan. Alternatif yang dipilih adalah yang paling banyak memberikan keuntungan, paling sedikit memiliki kelemahan, dan paling sedikit memberikan kerugian. Pemecahan masalah yang dipilih adalah Pelatihan dan Pendampingan pemrograman laravel untuk Siswa SMA IT Plus Bazma Briliant.

\section{B. Pelaksanaan Kegiatan}

Berdasarkan identifikasi masalah yang sudah dirumuskan dan tujuan yang hendak dicapai maka program pengabdian masyarakat ini dilakukan dalam 2 macam kegiatan yaitu :

I. Sosialisasi \& Workshop Pemrograman Laravel

Permasalahan bahwa banyak Siswa SMA IT Plus Bazma Briliant yang belum memiliki kemampuan yang cukup dalam membuat sebuah project menggunakan laravel serta siswa belum mampu menganalisa jika terjadi error dalam coding. Sosialisasi dan workshop dengan materi baku dan disesuaikan dengan kebutuhan praktis para mahasiswa. Pelatihan secara sinkron dilakukan di Laboratorium SMA IT Plus Bazma Briliant secara luring dengan tetap memperhatikan protokol kesehatan karena masih dalam masa pandemi covid 19.

2. Pendampingan Praktikum Pembuatan Program Laravel

Pendampingan dilakukan sebagai tindak lanjut pelatihan yang merupakan implementasi kemampuan membuat sebuah project berbasis laravel, yang terdiri dari:

a. Memahami Konsep MVC (Model View Controler)

b. Manipulasi Data, Controler dan user interface

c. Mengelola fitur fitur di laravel yang meliputi bundles, eloquent ORM, Application logic, Reverse Routing, Restfull controler, Class, View, Unit testing dan automatic Pagination

d. Pembuatan project sederhana berbasis laravel

\section{Evaluasi dan Pelaporan}

Pada setiap tahap dilakukan evaluasi sehingga timbul keyakianan bahwa segala sesuatu yang telah diputuskan adalah benar, dan dapat melangkah ke tahap berikutnya dengan aman. Apabila hasil evaluasi menunjukan kekurangan atau kelemahan maka dilakukan penyempurnaan atau penyesuaian.

Pada akhir kegiatan dilakukan analisa terhadap ketercapaian tujuan dan dampak dari keseluruhan kegiatan pengabdian masyarakat terhadap khalayak sasaran. Evaluasi juga dilakukan terhadap seluruh pelaksanaan kegiatan. Selanjutnya dilakukan penyusunan Laporan. Sebagai bentuk pertanggung jawaban pelaksanaan kegiatan pengabdian masyarakat yang telah dilakukan. 


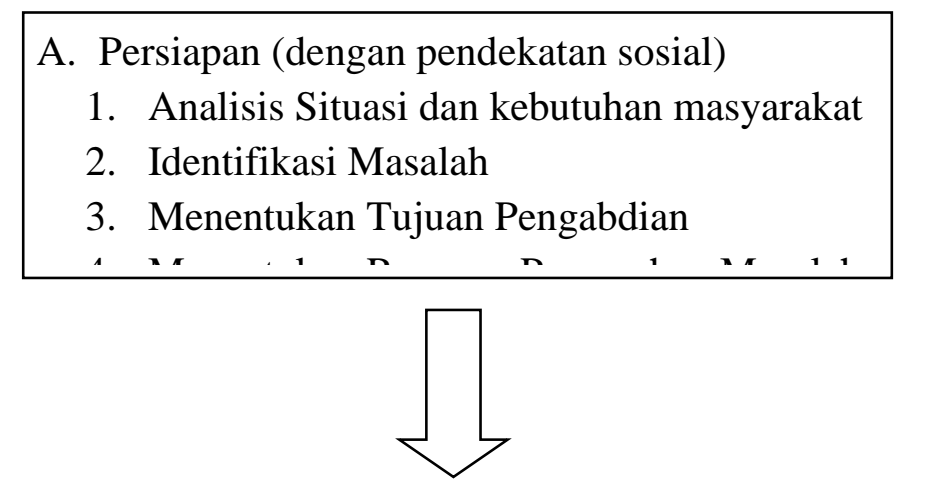

Evaluasi

B. Pelaksanaan Kegiatan Pengabdian

1. Pelatihan Pemrograman Laravel

Evaluasi

2. Pendampingan Pembuatan Project

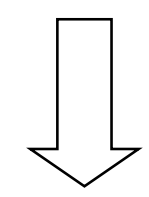

C. Evaluasi Hasil dan Pelaporan

Evaluasi

Gambar I. Tahapan Kegiatan Pengabdian Masyarakat

\section{PELAKSANAAN DAN PEMBAHASAN}

Pengabdian pada masyarakat ini dilaksanakan pada hari Rabu tanggal 3 I Maret 202 I di Laboratorium komputer dan dihadiri oleh siswa SMA IT Plus Bazma Brilliant dengan tetap menerapkan protokol kesehatan yaitu menjaga jarak dan memakai masker. Pelatihan ini dibuka langsung oleh bapak Sukanto, B.Irk selaku kepala sekolah SMA IT Plus Bazma Brilliant. Materi pertama disampaikan oleh Tri Handayani, MT yang membahas tentang pengenalan dasar materi framework laravel. Dalam sesi ini dosen memberikan informasi mengenai pemanfaatan framework laravel mulai dari memahami konsep mvc (model view controler), manipulasi data, controler dan user interface, mengelola fitur fitur di laravel yang meliputi bundles, eloquent orm, application logic, reverse routing, restfull controler, class, view, unit testing dan automatic pagination.
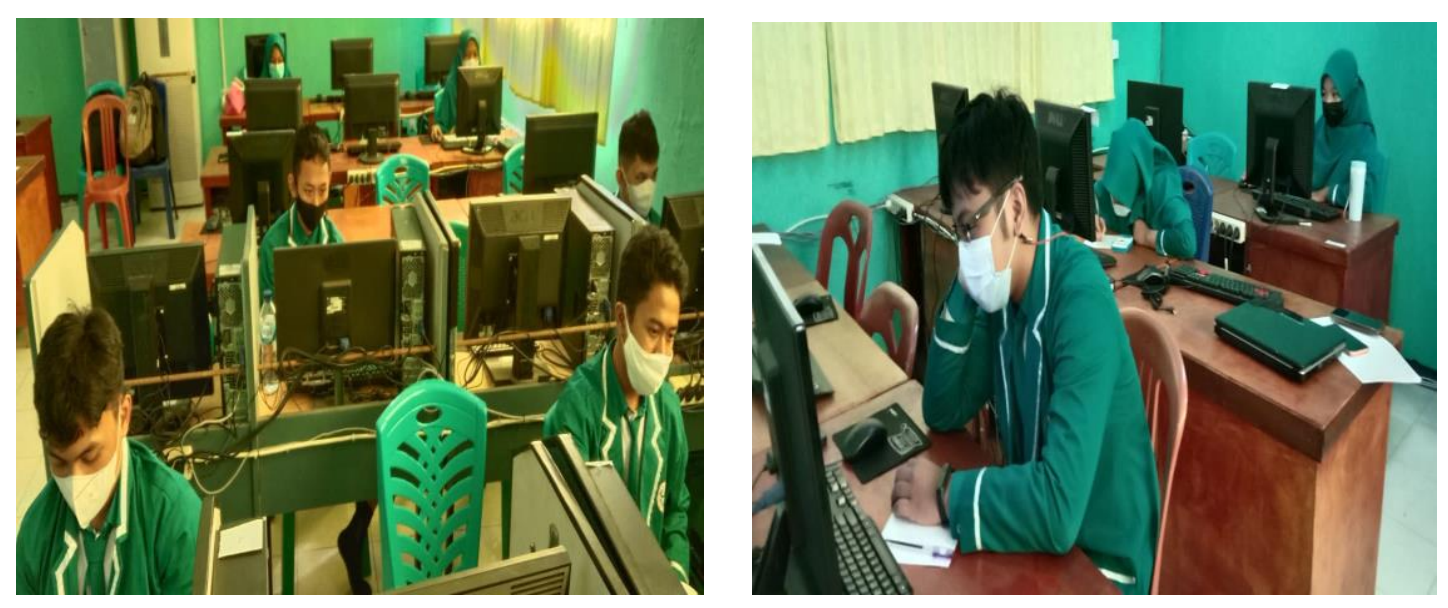

Gambar 2. Siswa SMA IT Plus Bazma Brilliant 
Pelatihan Pemograman Laravel pada Siswa SMA IT Plus Bazma Brilliant

Nur Budi Nugraha, Tri Handayani, Tri Yuliati, Ari Sellyana

Vol. 1, No. 2, Agustus 2021 hal. 130-136

DOI Artikel : 10.46306/jub.v1i2.28

Materi kedua disampaikan oleh bapak Nur Budi Nugraha, MT. Pada sesi ini dosen memberikan materi yang difokuskan pada praktek langsung menggunakan program laravel. Pada dasarnya ada dua cara untuk melakukan instalasi projek laravel, yaitu menggunakan laravel installer atau menggunakan via composer create project. Namun cara kedua yang paling umum digunakan. Sebelum memulai melakukan instalasi projek Laravel alangkah baiknya kita memeriksa terlebih dahulu apakah mesin atau komputer yang kita gunakan sudah terinstal composer atau belum dengan cara membuka comand prompt atau cmd dan mengetikan composer dan menekan enter. Jika muncul tulisan composer seperti pada gambar dibawah maka composer sudah terinstal. Selama kegiatan praktek, peserta pelatihan dibantu oleh dosen tim pengabdian.

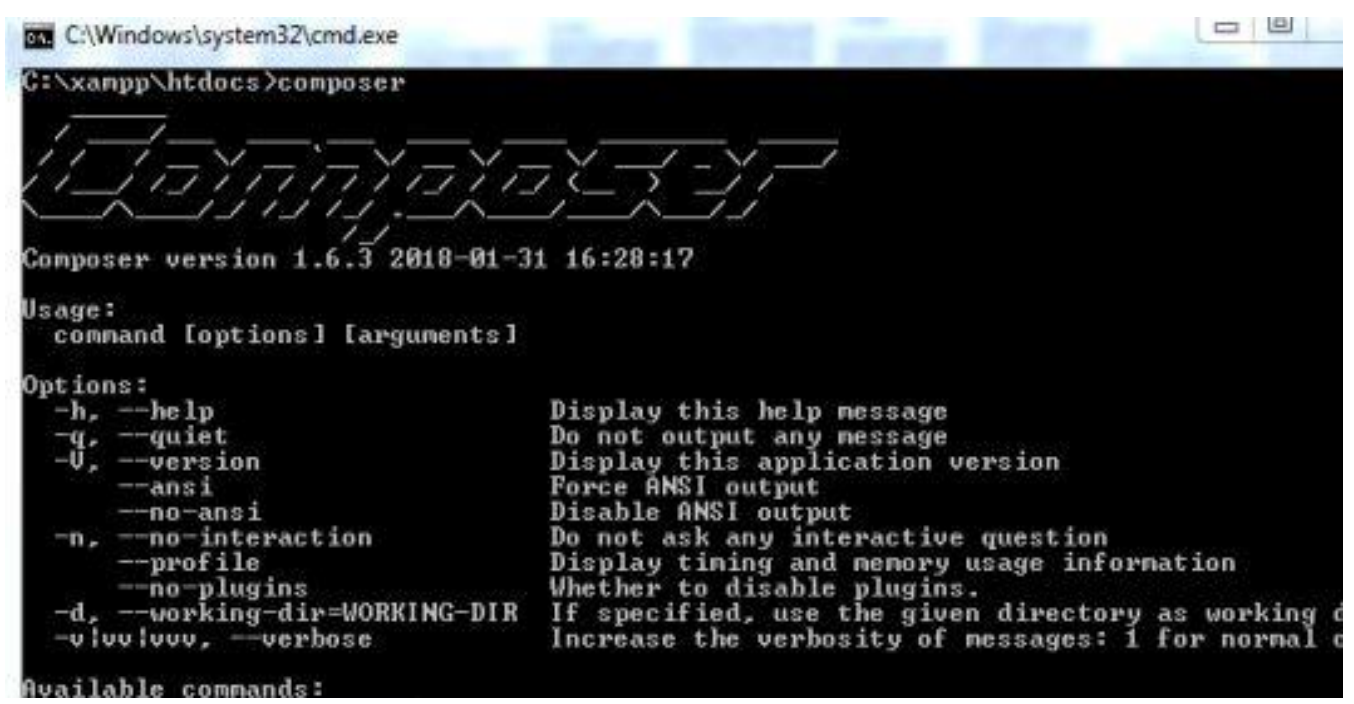

Gambar 3. Pengecekan Komposer

Secara umum kegiatan pengabdian ini berjalan lancar, dimulai dari kegiatan survei pendahuluan, pelaksanaan kegiatan pengabdian, sampai kepada penyusunan laporan. Berdasarkan diskusi yang diselenggarakan diperoleh kesimpulan bahwa para peserta pengabdian tersebut merasa senang dan puas. $\mathrm{Hal}$ ini terbukti dengan adanya permintaan dari para peserta agar kegiatan pengabdian ini tidak hanya diselenggarakan satu kali tetap harus berkelanjutan, mengingat pentingnya pembelajaran pemrograman laravel bagi siswa dalam menambah keahlian siswa untuk membuat sebuah projek sederhana.

Melalui pengabdian yang berkelanjutan akan terjalin hubungan kerjasama antara Sekolah Tinggi Teknologi Dumai dengan SMA IT Plus Bazma Brilliant. Hubungan kerjasama dalam hal pengembangan metode pembelajaran bagi sekolah sehingga program pengabdian masyarakat dapat berjalan maksimal yang menjadi salah satu kewajiban dosen Sekolah Tinggi Teknologi Dumai. Tingginya antusiasme peserta ditandai dengan banyaknya pertanyaan dan tingginya perhatian dari peserta sejak pengabdian dimulai hingga berakhir. Peserta pengabdian juga meminta agar pelatihan pemrograman framework laravel dapat dilanjutkan pada tahun mendatang dan disediakan kesempatan bagi para peserta untuk konsultasi lebih mendalam untuk semua materi pelatihan.

Faktor-faktor yang mendukung pelaksanaan pengabdian sehingga dapat terlaksana dengan lancar adalah tingginya antusiasme peserta pengabdian siswa SMA IT Plus Bazma Brilliant untuk mengikuti pelatihan pemrograman laravel. Manfaat yang besar atas tema pengabdian mengenai materi dan praktek framework laravel bagi siswa SMA IT Plus Bazma Brilliant dan fasilitas serta semangat tim pengabdi yang mendukung kelancaran pengabdian. Selain faktor pendukung, ada pula faktor penghambat yang mengakibatkan kegiatan pengabdian ini tidak mampu mencapai tujuan secara maksimal, yaitu waktu 
pengabdian hanya setengah hari dan singkat mengakibatkan peserta masih banyak ingin mendalami pemrograman framework laravel kurang maksimal dan musim pandemi covid sehingga jumlah peserta pengabdian ini terbatas untuk menghindari covid 19. Sehingga banyak siswa lain yang ingin ikutan tetapi tidak bisa ikut karena terbatasnya jumlah peserta kegiatan.

Hasil yang diperoleh dari pengabdian ini adalah sebagai berikut :

I. Peserta yang hadir pada acara pengabdian terbatas sejumlah 10 siswa dikarenakan sedang situasi pandemi covid dan terbatasnya ruangan labor dan siswa harus duduk dengan berjarak satu dengan yang lainnya.

2. Para peserta yang mengikuti pelatihan merasa senang dan puas dengan kegiatan pengabdian ini, hal ini terlihat dari ungkapan kepuasan serta keantusiasan peserta mendengarkan dan bertanya berbagai hal tentang materi yang telah diberikan oleh para pengabdi.

3. Kegiatan pengabdian ini dianggap oleh peserta sebagai sarana pengenalan dan pembelajaran framework laravel sebagai dasar belajar pemrograman untuk membuat sebuah projek sederhana.

4. Pada acara penutupan, hampir seluruh para peserta mengharapkan agar program serupa diadakan kembali untuk lebih memahami mengenai frame work laravel

\section{KESIMPULAN DAN SARAN}

Berdasarkan uraian pelaksanaan kegiatan pengabdian ini, maka dapat ditarik kesimpulan Peserta yang mengikuti pelatihan merasa senang dan puas dengan kegiatan pengabdian ini, hal ini terlihat dari ungkapan kepuasan serta keantusiasan peserta mendengarkan dan bertanya berbagai hal tentang materi yang telah diberikan oleh para pengabdi. Kegiatan pengabdian ini dianggap oleh peserta sebagai sarana pengenalan dan pembelajaran framework laravel sebagai dasar belajar pemrograman untuk membuat sebuah projek sederhana serta menjadi bekal bagi siswa yang ingin melanjutkan ke bangku perkuliahan dibidang teknik informatika.

\section{UCAPAN TERIMA KASIH}

Penulis mengucapkan terima kasih kepada Ketua Sekolah Tinggi Tinggi Dumai dan Ketua Lembaga Penelitian dan Pengabdian Kepada Masyarakat Sekolah Tinggi Tinggi Dumai yang telah memberikan bantuan dana dalam penyelenggaraan pengabdian masyarakat ini. Selain itu, penulis juga mengucapkan terima kasih kepada panitia dan peserta pelatihan sehingga acara ini dapat terlaksana dengan baik dan lancar.

\section{DAFTAR PUSTAKA}

Fransisca, M., Saputri, R. P., \& Yunus, Y. (202I). Workshop Dan Sosialisasi Pembuatan Blog Sebagai Media Knowledge Sharing Di Smk N I Sumbar. Jubaedah : Jurnal Pengabdian Dan Edukasi Sekolah (Indonesian Journal of Community Services and School Education), I(I), 28-36. https://doi.org/I0.46306/jub.v lil.6

Hapsari, I. N., Komputer, F. I., \& Unggul, U. E. (2020). PENYULUHAN MENGENAI PENGATURAN LARAVEL PADA WINDOWS, 6.

Ikhwani, Y., Hasbi, M., \& Andie, A. (2018). Pelatihan Penggunaan Aplikasi Dan Sistem Informasi Penerimaan

Peserta Didik Baru (Ppdb) Online Di Sma Negeri I Barabai. Jurnal Pengabdian Al-lkhlas, 3(I), 62-65. https://doi.org/l0.31602/jpai.v3il.934

IImi, U. R. (2019). Pelatihan Dan Pengkaderan Pembuatan Web Desa. Abdimas Berdaya, 2(I), 23-35.

Laurina, O. (2020). Analisis Cara Kerja Framework Laravel Untuk Perancangan E-Commerce Penjualan Hasil Pertanian. Osf.lo, (January). https://doi.org/I0.I3 I40/RG.2.2.33299.50726

Mahfudin Nawawi, M. M. (202I). Rancang Bangun Sistem Informasi Aspirasi Mahasiswa Berbasis Web Dengan Framework Laravel (Studi Kasus: BPM Fakultas Teknik Universitas Majalengka). IKRA-ITH 
Pelatihan Pemograman Laravel pada Siswa SMA IT Plus Bazma Brilliant

Nur Budi Nugraha, Tri Handayani, Tri Yuliati, Ari Sellyana

Vol. 1, No. 2, Agustus 2021 hal. 130-136

DOI Artikel : 10.46306/jub.v1i2.28

INFORMATIKA : Jurnal Komputer Dan Informatika, 5(2), 85-92. Retrieved from https://journals.upiyai.ac.id/index.php/ikraith-informatika/article/view/I00 I

Nugraha, N. B., Julanos, J., \& Suarlin, J. (2020). Peningkatan Kemampuan Berbahasa Inggris Bagi Siswa SMP. Madani : Indonesian Journal of Civil Society, 2(2), 22-27. https://doi.org// 0.35970/madani.v2i2.206

Oktaviani, I., Rini, I. A., Ulfah, M. M., \& Andriana, A. D. (202I). Pengenalan Media Pembelajaran Daring Berbasis Stem Untuk Guru Ipa Di Sman 9 Bandar Lampung. Jubaedah : Jurnal Pengabdian Dan Edukasi Sekolah (Indonesian Journal of Community Services and School Education), I(I), 77-88. https://doi.org// 0.46306/jub.vlil.16

Tujni, B., \& Megawaty, M. (2018). Pelatihan Pembuatan Web Dengan Php Pada Smp Negeri 27 Palembang. Jurnal Abdimas Mandiri, I(I), 37-40. https://doi.org/I 0.36982/jam.vlil.288 